\title{
Snowball Throwing untuk Meningkatan Kreativitas Siswa Pada Materi Pencemaran Lingkungan
}

\author{
${ }^{1}$ Nina Lindiani, ${ }^{2}$ Yeni Widiyawati, ${ }^{3}$ Diah Nugraheni \\ 1,2,3 Program Studi Pendidikan IPA, Fakultas Sains dan Teknologi, Universitas Ivet \\ Email_Korespondensi:_Ininalindi04@gmail.com,_2yeni.widiyawati26@gmail.com, \\ 3iah85heni@gmail.com
}

Article Info
Article History
Received: 08 October
2019
Revised: 25 January 2020
Published: 20 March 2020
Keywords Therning type
Cooperative Learning,
Snowball Throwing,
creativity, Environmental
Pollution.

Informasi Artikel

Sejarah Artikel

Diterima: 08 Oktober 2019

Direvisi: 25 Januari 2020

Dipublikasi: 20 Maret 2020

Kata kunci

Cooperative Learning tipe

Snowball Throwing,

kreativitas, Pencemaran

Lingkungan.

\begin{abstract}
This study aims to investigate the effectiveness of Cooperative LearningSnowball Throwing model to increase student creativity in Environment Pollution topics. Pretest-posttest control group design was used in this study. This study was conducted in SMP N 1 Bogorejo in May 2019. VII-B as experimental group and VII-C as the control group were used as the sample group which is taken by cluster random sampling technique. The data is collected by test and observation which based on fluency, flexibility, originality and elaboration as creativity indicators. $N$-Gain analysis and independent sample t-test was used to test the hypothesis. The t-test showed the significant differences of creativity between the experimental and control group. Therefor, Cooperative Learning-Snowball Throwing model is effective to increase student creativity on Environment Pollution topics.
\end{abstract}

Abstrak

Penelitian ini bertujuan untuk mengetahui efektivitas model Cooperative Learning tipe Snowball Throwing untuk meningkatkan kreativitas siswa pada materi Pencemaran Lingkungan. Penelitian ini menggunakan desain pretestpostest control group. Penelitian ini dilakukan di SMP N 1 Bogorejo pada bulan Mei 2019. Sampel yang digunakan adalah kelas VIIB sebagai kelas eksperimen dan kelas VIIC sebagai kelas kontrol yang diambil secara cluster random sampling. Data dalam penelitian ini dikumpulkan dengan teknik tes dan observasi yang mengacu pada indikator kreativitas yaitu fluency, flexibility, originality dan elaboration. Uji N-Gain dan independent sample t-test digunakan untuk menguji hipotesis. Hasil uji t menunjukkan terdapat perbedaan kreativitas siswa yang signifikan antara kelas kontrol dan eksperimen. Siswa pada kelas eksperimen memiliki kesempatan yang luas untuk mengembangkan kreativitas melalui sesi tanya jawab dengan teman sekelompok. Dengan demikian, dapat dikatakan bahwa penggunaan model pembelajaran Cooperative Learning tipe Snowball Throwing efektif untuk meningkatkan kreativitas siswa pada materi pencemaran lingkungan.

Sitasi: Lindiani, Nina., Widiyawati, Yeni \& Nugraheni, Diah. (2020). Snowball Throwing untuk meningkatkan kreativitas siswa pada materi pencemaran lingkungan. Science Education and Application Journal, 2(1), 1-10.

\section{PENDAHULUAN}

Guru perlu melakukan inovasi dalam pembelajaran sebagai upaya untuk meningkatkan daya serap materi serta keterampilan berpikir tingkat tinggi siswa atau higher order thinking skills (HOTS). Sesuai Taksonomi Bloom, Anderson \& Krathwohl (2001) mendefinisikan HOTS sebagai kemampuan menganalisis, mengevaluasi dan mencipta. Kemampuan HOTS juga dapat dikaitkan dengan atribut kemampuan berpikir kritis, kreatif, pemecahan masalah, pengambilan keputusan dan metakognisi (Yen \& Halili, 2015).

Beberapa studi menunjukkan bahwa keterampilan berpikir tingkat tinggi siswa masih rendah (Shidiq, Masykuri, \& H, 2015; Widiyawati, Nurwahidah, \& Sari, 2019). Berdasarkan penelitian yang telah dilakukan oleh Kurniati, Harimukti, \& Jamil, (2016) diketahui bahwa 
kemampuan siswa SMP dalam menyelesaikan soal HOTS berstandar PISA masih dalam kategor rendah. Berdasarkan observasi awal yang telah dilaksanakan di SMP N 1 Bogorejo, siswa di sekolah tersebut memiliki kemampuan rendah dalam menyerap materi IPA serta kurang kreatif dalam proses pembelajaran yang diukur berdasarkan indikator kreativitas. Sebagian besar siswa kurang aktif dalam pembelajaran serta belum mampu memberikan gagasan dalam rangka penyelesaian masalah.

Kreativitas merujuk pada kemampuan seseorang untuk menciptakan hal yang baru dan ide-ide baru yang dapat menyelesaikan masalah (Campbell, 2017). Indikator anak dikatakan kreatif diantaranya yaitu terkait dengan aspek (1) kelancaran (fluency), atau kemampuan mencetuskan banyak gagasan ;(2) Keluwesan (flexibility), atau kemampuan menghasilkan gagasan yang bervariasi. (3) Keaslian (originality), adalah kemampuan melahirkan ungkapan yang baru, unik, dan asli; (3) Elaborasi (elaboration)), atau kemampuan mengembangkan, memperkaya suatu gagasan sehingga menjadi lebih menarik (Nugraheni, 2018; Septaria 2019).

Berdasarkan riset mengenai kreativitas yang dilakukan di 139 negara menunjukkan bahwa Indonesia berada pada peringkat ke 67, di bawah Singapura dan Malaysia (Wibowo \& Karyaningsih, 2017). Sebagian besar sekolah di Indonesia hanya mementingkan peningkatan hasil belajar, dan guru kurang memberikan kesempatan yang luas kepada siswa untuk mengasah kreativitas (Kenedi, 2017). Idealnya, siswa didorong untuk belajar melalui penemuan, bukan belajar dengan cara menghafal pelajaran yang dipaksakan atau diberi instruksi (Doddington \& HIiton, 2010).

Berdasarkan studi pendahuluan yang telah dilakukan di SMP N 1 Bogorejo, beberapa siswa memiliki tingkat keberanian serta kemandirian yang rendah dalam menunjukan kreativitas dirinya. Mereka merasa percaya diri jika melakukan sesuatu besamaan dengan teman-temannya. Guru perlu menciptakan proses pembelajaran yang lebih banyak memberi ruang untuk meningkatkan kreativitas siswa, misal melalui cara pemecahan masalah, melakukan percobaan, dan mengembangkan gagasan (Kenedi, 2017).

Salah satu model pembelajaran yang dapat digunakan untuk meningkatkan kreativitas siswa yaitu adalah Cooperative Learning tipe Snowball Throwing. Melalui model ini, siswa dibiasakan untuk bekerja sama dalam rangka belajar dan bertanggung jawab dalam kegiatan kelompok (Al-Tabany, 2017). Model Cooperative Learning tipe Snowball Throwing dikembangkan berdasarkan pendekatan kontekstual sehingga dapat digunakan untuk meningkatkan kreativitas siswa (Mukaromah, Maftukhim, \& Fatmaryanti, 2013). Dalam pembelajaran berbasis Cooperative Learning tipe Snowball Throwing, siswa dilibatkan secara aktif dalam sesi tanya jawab antar kelompok yang dapat merangsang untuk berpikir kreatif dalam menjawab pertanyaan yang diajukan.

Berdasarkan penelitian yang telah dilakukan oleh Ernawati, Darminto, \& Maryam (2014) diketahui bahwa model pembelajaran Snowball Throwing efektif untuk meningkatkan kreativitas siswa. Model pembelajaran tersebut menuntut siswa untuk lebih aktif dan kreatif dalam pembelajaran. Oleh karena itu, model pembelajaran ini cocok untuk diterapkan pada mata pelajaran yang membutuhkan kreativitas dalam pemecahan masalah seperti materi pencemaran lingkungan. Materi ini dipilih sebab memiliki kompetensi dasar yang harus dicapai yaitu menjelaskan keterkaitan antara kegiatan manusia dengan masalah pencemaran 1 ingkungan dan pelestarian lingkungan (Astuti, 2017). Dengan demikian, tujuan penelitian ini yakni mengetahui efektivitas model pembelajaran Cooperative Learning tipe Snowball Throwing untuk meningkatkan kreativitas siswa pada materi pencemaran lingkungan. 


\section{METODE}

\section{Jenis Penelitian}

Penelitian ini menggunakan pretest-posttest control group design. Rancangan ini merupakan rancangan klasik dan tradisional yang menerapkan random assignment ( $\mathrm{R})$ pada partisipan dibentuk 2 kelompok dan menerapkan pre-test dan post-test (Creswell, 2013). Kedua kelas tersebut di bagi menjadi kelas eksperimen dan kelas kontrol. Kelas eksperimen diberikan perlakuan berupa penggunaan model pembelajaran Cooperative Learning tipe Snowball Throwing sedangkan kelas kontrol diberikan perlakuan dengan menggunakan model pembelajaran Cooperative Learning tipe Jigsaw. Model pembelajaran Jigsaw sering digunakan oleh guru dalam pembelajaran sehingga dianggap dapat digunakan sebagai kontrol. Prosedur penelitian ini secara rinci disajikan dalam Gambar 1.

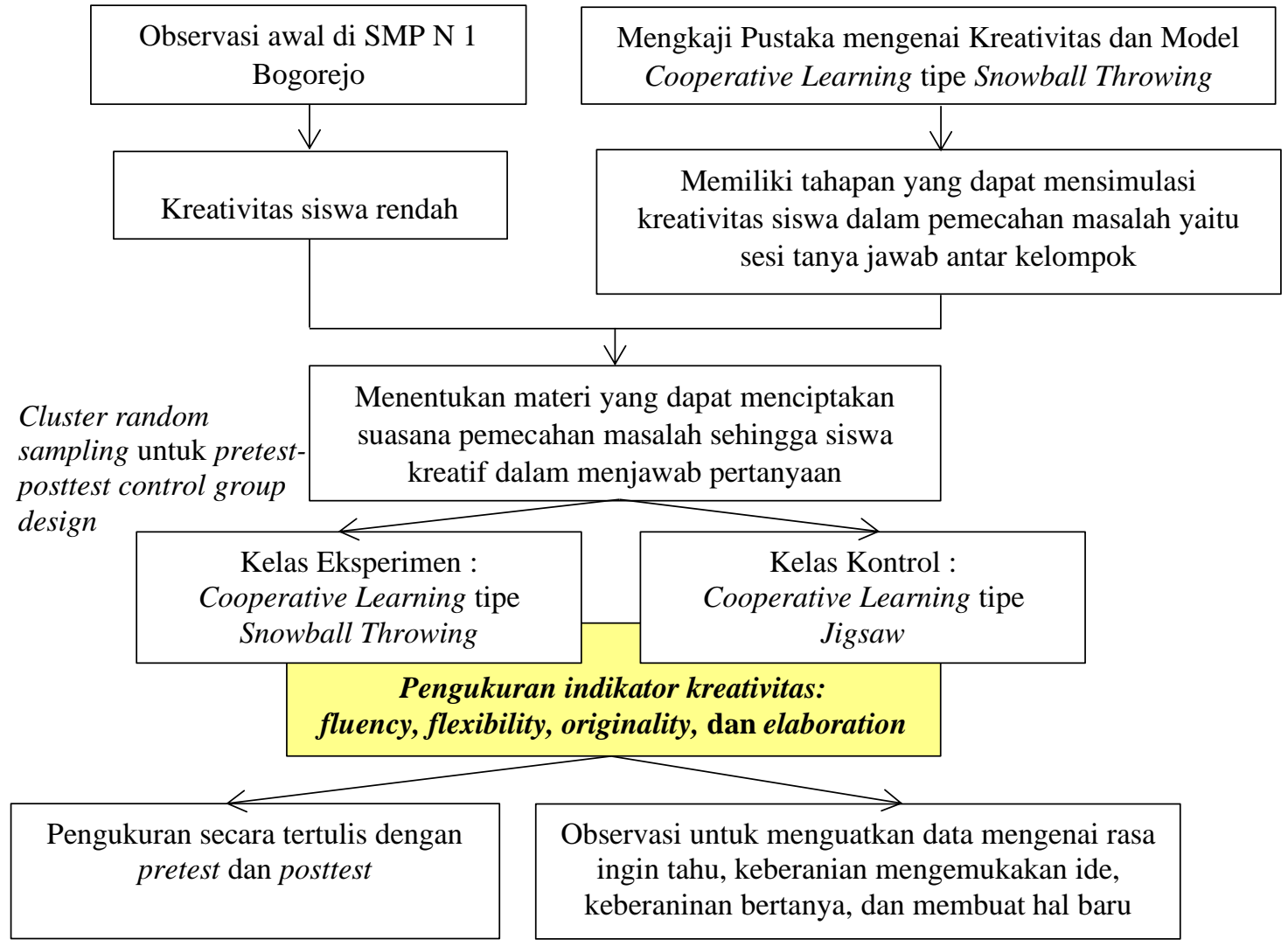

Gambar 1. Prosedur penelitian

\section{Waktu dan Tempat Penelitian}

Penelitian dilaksanakan SMP N 1 Bogorejo yang berada di Jl. Jatirogo Km.12 Kecamatan Bogorejo Kabupaten Blora pada bulan Mei 2019.

\section{Populasi dan Sampel}

Populasi dalam penelitian ini adalah 168 peserta didik kelas VII SMP N 1 Bogorejo semester genap tahun pelajaran 2018/2019. Adapun sampel yang digunakan dalam penelitian ini adalah siswa kelas VII A dan VII B yang diambil dengan teknik cluster random sampling. 


\section{Data, Intrumen, dan Teknik Pengumpulan Data}

Teknik pengumpulan data yang digunakan dalam penelitian ini yaitu tes secara tertulis serta observasi. Tes tertulis diberikan pada awal (pretest) dan akhir (posttest) untuk mengetahui kreativitas siswa. Indikator kreativitas yang digunakan dalam penelitian ini yaitu fluency, flexibility, originality dan elaboration (Nugraheni, 2018). Indikator tersebut kemudian dijabarkan dalam kisi-kisi soal kreativitas pada materi pencemaran lingkungan untuk siswa kelas VII semester genap. Soal yang digunakan berbentuk uraian yang terdiri dari 10 butir soal. Kisi-kisi soal tersebut secara lengkap disajikan dalam Tabel 1.

Tabel 1. Kisi-kisi Instrumen Tes Kreativitas

\begin{tabular}{|c|c|c|c|}
\hline $\begin{array}{l}\text { Indikator } \\
\text { Kreativitas }\end{array}$ & Indikator Soal & $\begin{array}{l}\text { No. } \\
\text { Butir }\end{array}$ & Kriteria Penskoran \\
\hline Elaboration & $\begin{array}{l}\text { Mendeskripsikan upaya } \\
\text { pelestarian lingkungan }\end{array}$ & 1 dan 2 & $\begin{array}{l}4: \text { bila menjawab dengan sangat tepat } \\
3: \text { bila menjawab tepat } \\
2: \text { bila menjawab kurang tepat } \\
1: \text { bila menjawab tidak tepat } \\
0: \text { bila tidak menjawab }\end{array}$ \\
\hline Originality & $\begin{array}{l}\text { Mendeskripsikan upaya } \\
\text { pelestarian lingkungan }\end{array}$ & 3 dan 4 & $\begin{array}{l}4: \text { bila menjawab orisinil dan penjelasan } \\
\quad \text { tepat } \\
3: \text { bila jawaban orisinil tetapi penjelasan } \\
\quad \text { kurang tepat } \\
2: \text { bila jawaban tidak orisinil dan } \\
\text { penjelasan } \\
\quad \text { tepat } \\
1: \text { bila jawaban tidak orisinil } \\
0: \text { bila tidak menjawab }\end{array}$ \\
\hline \multirow[t]{2}{*}{ Fluency } & $\begin{array}{l}\text { Mendiskripsikan upaya } \\
\text { pelestarian lingkungan }\end{array}$ & 5 & \multirow{2}{*}{$\begin{array}{l}\text { 4: bila menjawab lebih dari } 3 \text { dan jawaban } \\
\text { tepat } \\
\text { 3: bila menjawab } 3 \text { dan jawaban tepat } \\
2: \text { bila jawaban kurang dari } 3 \text { dan tepat } \\
1: \text { bila jawaban kurang dari } 3 \text { dan } \\
\text { jawaban } \\
\quad \text { tidak tepat } \\
0: \text { bila tidak menjawab }\end{array}$} \\
\hline & $\begin{array}{l}\text { Mengkomunikasikan } \\
\text { hasil penyelidikan tentang } \\
\text { pengaruh pencemaran } \\
\text { terhadap lingkungan }\end{array}$ & 6 dan 7 & \\
\hline \multirow[t]{2}{*}{ Flexibility } & $\begin{array}{l}\text { Memberi contoh } \\
\text { lingkungan yang tercemar }\end{array}$ & 8 & \multirow{2}{*}{$\begin{array}{l}4: \text { bila menjawab dengan sangat tepat } \\
3: \text { bila menjawab tepat } \\
2: \text { bila menjawab kurang tepat } \\
1: \text { bila menjawab tidak tepat } \\
0: \text { bila tidak menjawab }\end{array}$} \\
\hline & $\begin{array}{l}\text { Mendiskripsikan upaya } \\
\text { pelestarian lingkungan }\end{array}$ & 9 dan 10 & \\
\hline
\end{tabular}

\section{Teknik Analisis Data}

\section{a. Uji Instrumen}

Butir soal yang digunakan dalam pretest maupun posttes telah melalui proses validasi isi oleh ahli dan validasi konstruk validitas item dan reliabilitas instrumen.

\section{b. Uji Prasyarat}

Uji prasyarat yang dilakukan yaitu uji normalitas dan uji homogenitas. Asumsi normalitas data dan homogenitas data harus terpenuhi sebelum melakukan statistika parametrik yaitu uji-t.

1) Uji Normalitas

Uji normalitas digunakan untuk mengetahui data yang akan dianalisis tersebut terdistribusi normal atau tidak. Dalam penelitian ini, uji normalitas 
menggunakan rumus Kolmogorov-Sminov (Sugiyono, 2013). Rumus KolmogorovSmirnov disajikan dalam persamaan 1.

$$
K D: 1,36 \frac{\sqrt{n 1+n 2}}{n 1 n 2}
$$

Taraf signifikansi yang digunakan adalah $\alpha=0,05$. Uji normalitas menggunakan SPSS dengan kriteria yang digunakan untuk mengambil kesimpulan yaitu apabila nilai signifikansi lebih besar dari 0,05 ( sig > 0,05) maka data dikatakan normal, dan apabila nilai signifikansi lebih kecil dari 0,05 ( sig < 0,05 ), maka data dikatakan normal.

2) Uji Homogenitas

Uji homogenitas digunakan untuk mengetahui suatu data homogen atau tidak. Untuk mengukur homogenitas varians dari dua kelompok data, digunakan rumus uji F (Sugiyono, 2013) yang disajikan dalam persamaan 2.

$$
F=\frac{\text { Varian terbesar }}{\text { Varian terkecil }}
$$

Taraf signifikansi yang digunakan adalah $\alpha=0,05$. Uji homogenitas menggunakan SPSS dengan kriteria yang digunakan untuk mengambil kesimpulan yaitu apabila $\mathrm{F}_{\text {Hitung }}>\mathrm{F}_{\text {tabel }}$ maka memiliki varian yang homogen dan apabila $\mathrm{F}_{\text {Hitung }}$ $>\mathrm{F}_{\text {Tabel}}$, maka varian tidak homogen (Sugiyono, 2013).

\section{c. Uji Hipotesis}

\section{1) Gain Ternomalisasi (N-Gain)}

Uji gain ternormalisasi (N-Gain) dilakukan untuk mengetahui peningkatan hasil belajar siswa setelah diberikan perlakuan (Nirmalasari, Santiani, \& Rohmadi, 2016). Perhitungan skor gain ternormalisasi (N-Gain) dapat dinyatakan dalan persamaan 3.

$$
N-\text { Gain }=\frac{\text { Skor post test }- \text { Skor pre test }}{\text { Skor ideal-Skor pre test }}
$$

Adapun kriteria Gain Ternormalisasi diadopsi dari (Hake, 1998) dan disajikan dalam Tabel 2.

Tabel 2. Kriteria Gain Ternormalisasi

\begin{tabular}{|c|c|}
\hline Nilai $N$-Gain $(g)$ & Kategori \\
\hline$g \geq 0,7$ & Tinggi \\
\hline $0,3 \geq g>0,7$ & Sedang \\
\hline $\mathrm{g}<0,3$ & Rendah \\
\hline
\end{tabular}

2) Uji t

Teknik t-test (disebut juga t-score, tratio, t-technique, student-t) adalah teknik yang digunakan untuk menguji signifikansi perbedaan dua buah mean yang berasal dari dua buah distribusi (Margono, 2014). Adapun rumus uji t yang digunakan adalah independent sample t-test. Dalam penelitian ini taraf signifikansi yang digunakan $5 \%$. Kriteria pengujian adalah $\mathrm{H}_{1}$ diterima jika $\mathrm{t}_{\text {hitung }}>\mathrm{t}_{\text {tabel }}$ artinya 
ada perbedaan tingkat kreativitas yang signifikan antara siswa kelas kontrol dan kelas eksperimen. Begitu juga sebaliknya $\mathrm{H}_{0}$ diterima jika $\mathrm{t}_{\text {hitung }}<\mathrm{t}_{\text {tabel }}$ artinya tidak ada perbedaan tingkat kreativitas yang signifikan antara siswa kelas kontrol dan kelas eksperimen (Ghozali, 2013).

\section{HASIL DAN PEMBAHASAN}

\section{Analisis Uji Coba Instrumen}

a. Analisis Validitas

Analisis validitas digunakan untuk mengetahui valid tidaknya item tes. Berdasarkan uji coba soal yang telah dilaksanakan dengan jumlah peserta uji coba, $\mathrm{N}=$ 56 dan taraf signifikan 5\% didapat rtabel $=0,222$, jadi item soal dikatakan valid jika $\mathrm{r}_{\text {hitung }}>$ dari 0,222 . Dalam perhitungan validitas soal uji coba yang berjumlah 10 soal, keseluruhan soal dikatakan valid, sehingga pada penelitian ini peneliti menggunakan 10 soal untuk digunakan sebagai soal evaluasi pretest dan posttest pada kelas eksperimen dan kelas kontrol.

b. Analisis Reliabilitas

Uji reliabilitas digunakan untuk mengetahui tingkat konsistensi instrumen. Instrumen yang baik secara akurat akan memberikan hasil pengukuran yang sama serta memiliki jawaban yang konsisten untuk kapanpun instrumen tersebut digunakan. Hasil perhitungan koefisien reliabilitas 10 butir soal diperoleh $r_{\text {Alpha }}=0,723$ dan $r_{\text {Tabel }}=0,222$. Maka dapat disimpulkan bahwa instrumen soal dikatakan reliabel, karena $r_{\text {Alpha }}>t_{\text {tabel. }}$.

\section{Uji Prasyarat Analisis}

\section{a. Uji Normalitas}

Uji normalitas dilakukan untuk menguji apakah semua data memenuhi kurva distribusi normal atau tidak. Uji normalitas menggunakan rumus Kolmogorov-Smirnov dalam perhitungan menggunakan program SPSS. Untuk mengetahui normal atau tidaknya ampel yang digunakan adalah jika sig > 0,05 maka data terdistribusi normal dan jika sig $<0,05$ dapat dikatakan data tidak berdistribusi normal. Hasil perhitungan disajikan dalam Tabel 3.

Tabel 3. Hasil Uji Normalitas

\begin{tabular}{|c|c|c|c|}
\hline No & Kelompok & Sig & Kesimpulan \\
\hline 1 & Eksperimen & 0,200 & Normal \\
\hline 2 & Kontrol & 0,171 & Normal \\
\hline
\end{tabular}

Berdasarkan data pada Tabel 3, terlihat bahwa data pre-test dan post-test hasil belajar kreativitas siswa baik kelas ekperimen dan kelas kontrol memiliki nilai sig > 0,05, maka dapat disimpulkan kelompok data tersebut berdistribusi normal.

b. Uji Homogenitas

Uji homogenitas digunakan untuk mengetahui tingkat kesamaan varians antara dua kelompok yaitu kelompok eksperimen dan kelompok kontrol. Untuk menerima atau menolak hipotesis dengan membandingkan harga sig pada levene's statistic dengan 0,05 (sig > 0,05). Hasil uji homogenitas disajikan dalam Tabel 4.

Tabel 4. Hasil Uji Homogenitas

\begin{tabular}{|l|c|c|c|}
\hline \multicolumn{1}{|c|}{ Kelas } & F $_{\text {hitung }}$ & Sig & Ket \\
\hline Pre-test & 0,587 & 0,190 & Homogen \\
\hline Post-test & 18,751 & 0,796 & Homogen \\
\hline
\end{tabular}


Dari hasil homogenitas variabel penelitian diketahui nilai $\mathrm{F}_{\text {hitung }}$ pre-test 0,587, dengan nilai sig 0,190. Pre-test dinyatakan homogen karena nilai sig $>0,05$. Nilai $F_{\text {hitung }}$ post-test 18,751 dengan sig 0,796. Post-test dinyatakan homogen karena nilai sig > 0,05 . Maka dapat disimpulkan bahwa data dalam penelitian ini memiliki varians yang homogen.

\section{Pengujian Hipotesis}

Penelitian ini bertujuan untuk mengetahui efektivitas model Cooperative Learning tipe Snowball Throwing untuk meningkatkan kreativitas siswa pada materi pencemaran lingkugan. Uji hipotesis yang dilakukan yaitu uji N-Gain dan uji beda yaitu uji-t. Data yang digunakan dalam uji hipotesis berupa data interval yang diperoleh dari hasil pre-test dan post-test. Sementara itu, data yang diperoleh dari observasi berfungsi sebagai penguat hasil tes. Analisis statistik deskriptif N-Gain kedua kelas disajikan dalam Tabel 5.

Tabel 5. Statistik Deskriptif N-Gain

\begin{tabular}{|c|c|c|c|c|c|c|}
\hline Kelas & $\mathbf{N}$ & Min & Maks & Mean & Sb & Var. \\
\hline Eksperimen & 28 & 0,15 & 0,86 & 0,56 & 0,185 & 0,034 \\
\hline Kontrol & 28 & 0,04 & 0,68 & 0,40 & 0,167 & 0,028 \\
\hline
\end{tabular}

Berdasarkan Tabel 5 terlihat bahwa rata-rata (Mean) N-gain yang diperoleh siswa pada kelas eksperimen maupun kelas kontrol masuk dalam kategori sedang. Namun, nilai rata-rata $\mathrm{N}$-gain eksperimen lebih tinggi daripada kelas kontrol. Secara lebih detail N-Gain kedua kelas disajikan dalam Gambar 2.

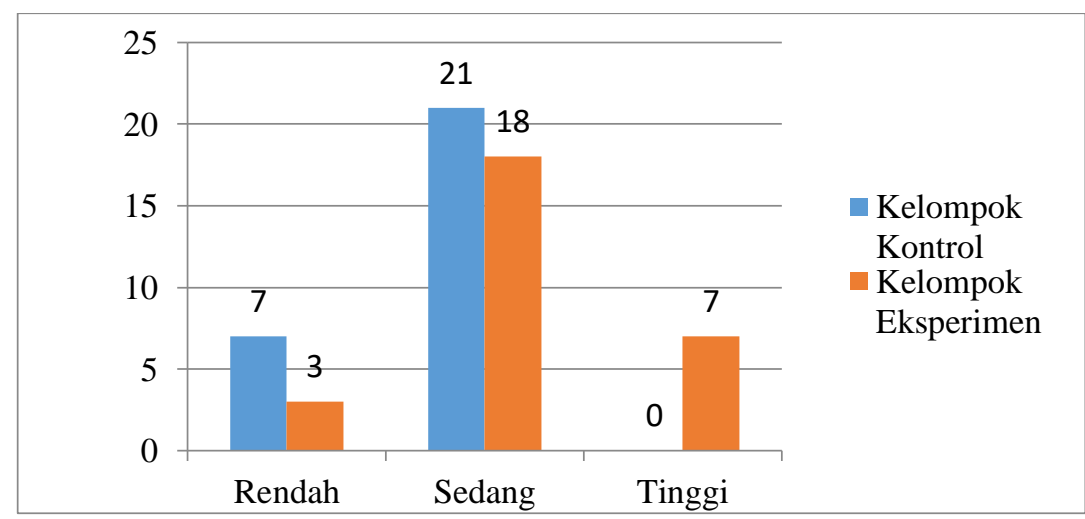

Gambar 2. Diagram Perbandingan Kategori N-Gain Kelas Kontrol dan Eksperimen

Berdasarkan Gambar 2, dapat diketahui bahwa tidak ada satupun siswa pada kelas kontrol yang memperoleh N-Gain pada kategori tinggi. Peningkatan kreativitas siswa pada kelompok kontrol didominasi pada kategori sedang. Di lain sisi, hanya 3 siswa pada kelompok eksperimen yang termasuk dalam kategori N-Gain rendah. Dengan demikian, dapat disimpulkan bahwa peningkatan kreativitas siswa kelas eksperimen lebih tinggi daripada kelas kontrol. Peningkatan kreativitas yang tidak berbeda jauh antara kedua kelompok ini disebabkan karena kelompok kontrol telah mendapatkan pembelajaran berbasis Cooperative Learning tipe Jigsaw. Model ini menyiapkan siswa untuk aktif mengemukakan pendapat dan berkoordinasi dalam kelompok (Ridwan \& Sumadi, 2015; Susilo \& Sunarno, 2016). Jigsaw cocok untuk mengembangkan keterampilan menulis, membaca dan mendengarkan (Dediansyah, Akhyar, \& Musadad, 2016). Hal ini senada 
dengan hasil penelitian Ridwan \& Sumadi (2015) yang menyatakan bahwa Jigsaw efektif meningkatkan prestasi belajar, motivasi dan kreativitas siswa SMP pada materi IPA fisika.

Uji hipotesis yang kedua yaitu independent-sample t-test skor $\mathrm{N}$-Gain kelas eksperimen dan kelas kontrol. Uji ini bertujuan untuk mengetahui ada tidaknya perbedaan yang signifikan antara kelas eksperimen dan kelas kontrol. Hasil analisis uji t disajikan dalam Tabel 6.

Tabel 6. Hasil Uji independent sample t-test

\begin{tabular}{|l|c|c|c|c|r|}
\hline \multirow{2}{*}{ Kreativitas } & \multicolumn{2}{|c|}{ Uji-F } & \multicolumn{3}{c|}{ Uji-t } \\
\cline { 2 - 6 } & $\mathrm{F}$ & \multicolumn{1}{c|}{ Sig } & \multicolumn{1}{c|}{ T } & \multicolumn{1}{c|}{ Df } & Sig. (2-tailed) \\
\hline Equal variances assumed & 0,226 & 0,636 & 3.475 & 54 & 0.001 \\
\cline { 1 - 4 } & & & 3.475 & 53.414 & 0.001 \\
\hline
\end{tabular}

Dari hasil perhitungan Independent Sample t-test pada kreativitas dapat dilihat bahwa nilai $F=0,226$ dengan tingkat signifikansi 0,812. Dengan demikian probabilitas lebih dari 0,05 . Kenyataan ini menunjukkan bahwa sesungguhnya varians kreativitas antara kelas eksperimen dan kelas kontrol adalah sama. Berdasarkan penjelasan di atas, maka dalam pengujian t akan digunakan asumsi kedua varian sama (equals variances assumed) (Ghozali, 2013). Dari tabel 6 dapatt dilihat nilai t untuk varians sama adalah 3,475 dengan taraf signifikansi 0,001. Nilai $\mathrm{t}$ tabel untuk $\mathrm{df}=54$ adalah 2,004. Karena nilai $\mathrm{t}_{\text {hitung }}>\mathrm{t}_{\text {tabel }}$ yaitu $t_{\text {hitung }}=3,475$ lebih besar dari $\mathrm{t}_{\text {tabel }}=2,004$ pada taraf sig $5 \%$, maka $\mathrm{H}_{0}$ ditolak. Dari uraian tersebut diketahui bahwa terdapat perbedaan tingkat kreativitas yang signifikan siswa VII SMP N 1 Bogorejo materi pencemaran lingkungan antara kelas kontrol dan kelas eksperimen.

Berdasarkan hasil observasi diketahui bahwa siswa pada kelas eksperimen lebih aktif melakukan diskusi dalam kelompok untuk mencari tahu mengenai materi yang sedang dibahas yaitu pencemaran lingkungan. Siswa dilatih untuk bekerjasama dengan teman sekelompok sehingga mereka dapat terlibat secara aktif dalam pembelajaran. Penelitian Salahuddin, Yusuf, \& Budiono (2018) menunjukkan bahwa teman sebaya dapat mengembangkan motivasi belajar siswa. Pengaruh teman sebaya juga membuat siswa dapat lebih memahami materi dan bebas mengekspresikan diri untuk bertanya jika mereka belum memahami materi yang disampaikan oleh teman sekelompok. Isti'adah \& Permana (2017) dalam penelitiannya mengemukakan bahwa bahwa teman sebaya dalam satu kelompok dapat meningkatkan kemampuan berkomunikasi serta keberanian yang lebih tinggi. Siswa mampu mengemukakan ide melalui sesi membuat pertanyaan dan menjawab pertanyaan, dimana dalam sesi ini siswa bebas untuk mengembangkan pertanyaan serta memiliki wadah untuk menjawab pertanyaan sesuai dengan apa yang mereka pikirkan sehingga mereka dapat menciptakan hal-hal baru.

Siswa pada kelas eksperimen memiliki ruang untuk mengeksprekisan kreativitas mereka dalam penyelesaian masalah dari soal-soal yang mereka dapatkan sehingga siswa dapat berpikir kreatif. Observasi pada kelas eksperimen menunjukkan bahwa sebagian besar siswa memiliki ciri-ciri kreatif yaitu memiliki rasa ingin tahu serta berani bertanya. Beberapa siswa selalu bertanya ketika mereka merasa kurang paham dengan materi. Mereka antusias dan kreatif dalam menjawab pertanyaan teman satu kelompok sebab model Cooperative Learning tipe Snowlball Throwing menginisasi adanya penerapan punishment yang mendidik. Dengan demikian, dapat disimpulkan bahwa model Cooperative Learning tipe Snowball Throwing efektif untuk meningkatkan kreativitas. Hal ini senada dengan penelitian 


\section{KESIMPULAN}

Berdasarkan penelitian eksperimen yang telah dilaksanakan dapat disimpulkan bahwa model Cooperative Learning tipe Snowball throwing efektif untuk meningkatkan kreativitas siswa pada materi pencemaran lingkungan.

\section{SARAN}

Dari hasil penelitian yang telah dilaksanakan, saran yang diajukan peneliti adalah (1) Bagi sekolah, disarankan agar proses belajar mengajar dengan menggunakan model pembelajaran Cooperrative Learning Tipe Snowball Throwing dikembangkan para guru untuk dapat digunakan pada saat pembelajaran di kelas. (2) Bagi pendidk, disarankan agar dapat menggunakan model pembelajaran Cooperrative Learning Tipe Snowball Throwing pada mata pelajaran IPA ataupun dapat menerapkan model pembelajaran Cooperrative Learning Tipe Snowball Throwing pada mata pelajaran yang lain, sehingga pembelajaran lebih efektif dan menyenangkan. (3) Bagi peneliti, diharapkan dapat mengembangkan kembali penelitian dengan menggunakan model pembelajaran Cooperrative Learning Tipe Snowball Throwing materi lainnya.

\section{UCAPAN TERIMA KASIH}

Peneliti mengucapkan terimakasih kepada Kepala Sekolah, Guru Mata Pelajarana, staf dan siswa siswi SMP N 1 Bogorejo yang telah mendukung dan membantu dalam memberikan data maupun informasi untuk tujuan penelitian.

\section{DAFTAR PUSTAKA (12pt)}

Al-Tabany, T. I. (2017). Mendesain model pembelajaran inovatif, progresif, dan kontekstual. Jakarta: Kencana.

Anderson, L. W., \& Krathwohl, D. R. (2001). A Taxonomy for learning, teaching, and assessing: A revision of Bloom's taxonomy of educational objectives. Boston: Allyn \& Bacon.

Astuti, P. (2017). Peningkatan motivasi siswa dan kemampuan berpikir kreatif siswa pada materi pencemaran lingkungan melalui media fotonovela. Refleksi Edukatika, 8(1), $36-42$.

Creswell, J. W. (2013). Research design: pendekatan kualitatif, kuantitatif, dan mixed (III). Yogyakarta: Pustaka Pelajar.

Dediansyah, A., Akhyar, M., \& Musadad, A. A. (2016). Perbedaan pengaruh model pembelajaran jigsaw dan make a match terhadap prestasi belajar sejarah ditinjau dari kreativitas belajar siswa kelas XI SMA negeri di Kabupaten Sambas Tahun 2015/2016. Historika, 16(1), 42-53.

Doddington, C., \& HIiton, M. (2010). Pendidikan berpusat pada anak. Jakarta: PT Indeks Istarani.

Ernawati, D., Darminto, B. P., \& Maryam, I. (2014). Upaya meningkatkan kreativitas dan prestasi belajar matematika siswa dengan model pembelajaran snowball throwing. Jurnal Pendidikan Matematika, 15(2), 87-92.

Ghozali, I. (2013). Aplikasi analisis multivariate dengan program IBM SPSS 21. Semarang: Badan penerbit Universitas Diponegoro.

Hake, R. (1998). Interactive-engagement versus traditional methods : a six-thousand- 
student survey of mechanics test data for introductory physics courses. American Journal of Physics, 66(1), 64-74.

Isti'adah, F. N., \& Permana, R. (2017). Peran kelompok teman sebaya di sekolah dalam meningkatkan komunikasi interpersonal siswa. Psikopedagodia, 6(1), 8-13.

Kenedi, K. (2017). Pengembangan kreativitas sisiwa dalam proses pembelajaran di kelas II SMP Negeri 3 Rokan IV Koto. Jurnal Pendidikan Sosial, Sains, Dan Humaniora, 3(2), 329-347.

Septaria, K. (2019). Mengeksplorasi Argumentasi dan Pengetahuan Pendidik Ilmu Pengetahuan Alam (IPA) Tentang Pemanasan Global [Exploring the Arguments and Knowledge of Natural Sciences (IPA) Educators on Global Warming]. PEDAGOGIA: Jurnal Pendidikan, 8(2), 247-256.

Kurniati, D., Harimukti, R., \& Jamil, N. A. (2016). Kemampuan berpikir tingkat tinggi siswa SMP di Kabupaten Jember dalam menyelesaikan soal berstandar PISA. Jurnal Penelitian Dan Evaluasi Pendidikan, 20(2), 142-155. https://doi.org/DOI: http://dx.doi.org/10.21831/pep.v20i2.8058

Margono, S. (2014). Metodologi penelitian pendidikan. Jakarta: Rineka Cipta.

Mukaromah, A., Maftukhim, A., \& Fatmaryanti, S. D. (2013). Peningkatan kreativitas belajar fisika menggunakan model pembelajaran snowball throwing pada siswa kelas X SMA Negeri 1 Klirong. Radiasi, 3(2), 98-102.

Nirmalasari, N., Santiani, S., \& Rohmadi, H. M. (2016). Penerapan model pembelajaran learning cycle terhadap ketrampilan proses sains dan hasil belajar siswa pada pokok bahasan getaran harmonis. EduSains, 4(2), 79-94.

Nugraheni, D. (2018). Pengembangan lembar kegiatan siswa (LKS) berbasis inquiry materi pengukuran untuk meningkatkan kreativitas siswa. Natural, 5(2), 98-103. https://doi.org/10.30738/natural.v5i2.3252

Ridwan, A., \& Sumadi, S. (2015). Upaya meningkatkan motivasi, kreativitas, dan prestasi belajar IPA dengan implementasi model pembelajaran kooperatif tipe Jigsaw. Wiyata Dharma, V(1), 44-48.

Salahuddin, M., Yusuf, N., \& Budiono, B. (2018). Pengaruh teman sebaya terhadap perkembangan motivasi belajar siswa di SMP Muhammadiyah 1 Malang. Civic Hukum, 3(1), 52-61.

Shidiq, A. S., Masykuri, M., \& H, E. S. V. (2015). Analisis higher order thinking skills (HOTS) menggunakan instrumen two-tier multiple choice pada materi kelarutan dan hasil kali kelarutan untuk siswa kelas XI SMA N 1 Surakarta. In Prosiding Seminar Nasional Pendidikan Sains (SNPS) (pp. 159-166). Surakarta: FKIP UNS.

Sugiyono, S. (2013). Metode penelitian kuantitatif, kualitatif dan R\&D. Bandung: Alfabeta.

Susilo, F., \& Sunarno, W. (2016). Pembelajaran fisika menggunakan model Jigsaw dan GI (Group Investigation) ditinjau dari kreativitas dan sikap ilmiah belajar siswa. Jurnal Inkuiri, 5(3), 40-48.

Wibowo, A., \& Karyaningsih, R. D. (2017). Hubungan kreativitas, efikasi diri dan intensi berwirausaha pada mahasiswa. Jurnal Pendidikan Ekonomi Dan Bisnis, 5(2), 163175.

Widiyawati, Y., Nurwahidah, I., \& Sari, D. S. (2019). Pengembangan instrumen integrated science test tipe pilihan ganda beralasan untuk mengukur HOTS peserta didik. 
Saintifika, 21(2), 1-14.

Yen, T. S., \& Halili, S. H. (2015). effective teaching of higher-order thinking (HOT) in education. The Online Journal of Distance Education and E-Learning, 3(2), 41-47. 